\title{
Effectiveness of Using Google Forms in the Problem Based Learning Model to Increase the Critical Thinking Ability of High School Students
}

\author{
Erni Endah Sari \\ Master of Program in Chemistry \\ Education \\ Mulawarman University \\ Samarinda, Indonesia \\ erni181181@gmail.com
}

\author{
Usman \\ Master of Program in Chemistry \\ Education \\ Mulawarman University \\ Samarinda, Indonesia \\ sainusman@ymail.com
}

\author{
Abdul Hakim \\ Department of Physics Education \\ Mulawarman University \\ Samarinda, Indonesia \\ abdul.hakim@fkip.unmul.ac.id
}

\begin{abstract}
This study aims to examine the effectiveness of using Google Forms in the Problem Based Learning (PBL) model to improve the critical thinking skills of high school students. The research method used experimental research through the nonequivalent control group. The experiments used in this study were quasi-experimental. The research was conducted in XI IPA class at SMA Negeri 10 Samarinda. The sample in this study were 30 students of XI IPA 9 as a control class and XI IPA 10 as an experimental class as much as 31 students. Evaluation in a critical thinking ability test in multiple choice tests with 25 questions. Evaluations are carried out using Google Forms and given in pre-test and post-test. Questionnaire of form responses for students and validators. Observation is using for learning activity. The effectiveness of the learning studied was assessed using the effect size. The results showed that the average $\mathrm{N}$-gain score of critical thinking skills students of the experimental group was 0.69 and the control group was 0.55 so an effect size was obtained as 0.802 . Based on the effect size data obtained are included in the high category. So it can be concluded that learning using the Problem Based Learning (PBL) model assisted by Google Forms is effective in improving students critical thinking skills.
\end{abstract}

Keywords: Problem Based Learning (PBL), Google Forms, critical thinking skills

\section{INTRODUCTION}

In the learning process in the classroom, currently, there are still educators who position students as learning objects, not as individuals who have to develop their potential. This can hinder or even kill the potential of students. In these circumstances, students only listen to teacher lectures in front of the class, so it is easy for students to feel bored with the material provided. As a result, students do not understand what the teacher just said.

In the problem-based learning model, the teacher's role is to provide various problems, provide questions, and facilitate investigation and discussion. The teacher gives students the opportunity to set the topic of the problem to be discussed, even though the teacher has actually set the topic of what the problem should be discussed. The most important thing is the teacher provides a supporting framework that can improve the ability of inquiry and intelligence of students in thinking.

Critical thinking is thinking that examines, connects, and evaluates all aspects of a situation or problem. This includes collecting, organizing, remembering, and analyzing information. Critical thinking includes the ability to read with understanding and identify material that is needed and not needed. It also means being able to draw conclusions from the data provided and be able to determine inconsistencies and disagreements within a group of data. Critical thinking is analytical and reflexive.

Chemistry is a part of science which in essence as a collection of knowledge can be in the form of facts, concepts, principles, laws, theories, and models commonly called products besides the most important thing in science are the process of learning. In addition to providing knowledge to students, chemistry is a vehicle for growing the ability to think and solve problems in everyday life. In fact, chemistry teachers generally tend to use the lecture method. Teachers tend to use these methods due to time constraints, the pursuit of inadequate material and infrastructure.

The learning process in SMA Negeri 10 Samarinda for chemistry so far is still dominated by the teacher so that it has not provided an opportunity for students to develop independence through discovery and thought processes. The way teachers teach only one direction (teacher-centered) causes a buildup of information or concepts that are less useful for students. The teacher always requires students to learn but does not teach how students should learn and solve problems.

In the 2013 curriculum, it is hoped that $21 \mathrm{st}$ century learning can be integrated. This is to address the demands of an increasingly competitive era. The 21 st century learning reflects three things namely 1 ) Critical Thinking and Problem Solving, 2) Creativity and Innovation and 3) Communication and Collaboration. Teachers in the current era of 
(PBL) model with the Google Forms in the experimental class and applying the Problem Based Learning (PBL) learning model without the Google Forms to the control class. The final action taken by the researcher is to provide a final test (posttest), the goal is to get a comparison of data from pretest to posttest. The design of this study can be described as follows [4]: goals [7].

Based on preliminary studies (based on national examination) the researcher does, students have a fairly high ability in knowledge but the problem that arises in the field is that although students get high grades in a number of subjects, they seem less able to apply their acquisition, both in the form of knowledge, skills and attitudes to in other situations, learning that has been carried out emphasizes more on the aspects of knowledge and understanding, the application aspect is only a small part carried out, while the aspects of analysis, evaluation and creation are less even never done.

In this research will be used Google Forms in the version of Google Suite for Education (G-Suite for Education) as a tool for developing instructional media tools because this tool with certain techniques has the ability to start from the management of teaching materials, assessment, and evaluation to an analysis of results student absorption. All material has been added to Google Forms with the concept of Flipped Learning, when face to face in class, the teacher can focus more on a problem based approach. For this reason, researchers chose Google Forms version of Google Suite as a tool for developing online learning media tools that are very reliable in terms of connectivity, unlimited storage capacity, high level of security and have feature Single Sign On (SSO) so that it can be integrated with all accounts and other Google applications that can be developed easily because they can be designed without programming code (script) or in other words the design is based on visuals.

\section{METHOD}

In this study using experimental research. Experimental research is examining the effect of treatment on behavior that appear as a result of treatment [1]. Experimental research is research conducted to find out the consequences appear from a treatment given intentionally by researchers [5]. Experimental research in basicly can be defined as a systematic method for building relationships that contain causal-effect relationships [9].

Based on the description above, this study design uses "nonequivalent control group design" or "Pretest and Postest Design". This study uses two groups, the first group as an experimental class and the second group as a control class. Pretest is given to students to determine the extent to which critical thinking skills possessed by students regarding the learning of acidbase solutions. After being given a Pretest, applying acid-base learning with the Problem Based Learning

\section{Group Treatment: $\mathrm{O} \quad \mathrm{X} \quad \mathrm{O}$ \\ Controlclass: $\quad$ O $\mathrm{C} \quad \mathrm{O}$

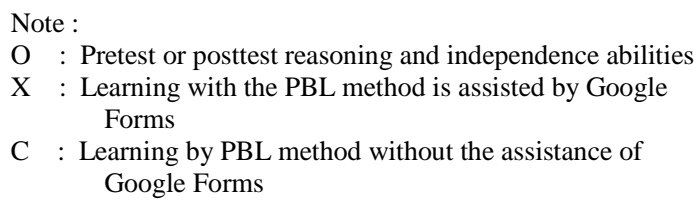

Critical thinking skills test in the form of multiple choice tests totaling 25 questions. Evaluations are carried out using Google Forms and given in pre-test and post-test forms. This test is carried out on the experimental class and the control class in carrying out the learning process of acid-base solution. This instrument is used to measure the improvement of students' critical thinking skills and assess the effectiveness of the learning process using the Google Forms with Problem Based Learning (PBL) model.

The data analysis technique used is a statistical test. In this study the statistical techniques used are the $\mathrm{N}$-gain and effect size techniques. Increased student competence before and after learning can be calculated by the formula $\mathrm{g}$ factor (N-Gains):

$$
\mathrm{g}=\frac{S_{\text {Post }}-S_{\text {Pre }}}{S_{\text {maks }}-S_{\text {Pre }}}
$$

High and low normalized gain (N-Gains) can be classified as follows:

TABLE 1. N-GAINS CRITERIA

\begin{tabular}{|c|c|}
\hline N-Gains & Category \\
\hline $\mathrm{g} \geq 0,7$ & High \\
\hline $0,7>\mathrm{g} \geq 0,3$ & Medium \\
\hline $\mathrm{g}<0,3$ & Low \\
\hline
\end{tabular}

The effectiveness of the study was assessed based on effect size, which is a method to find out how much the effectiveness of learning with the Problem Based Learning (PBL) model assisted by Google Forms is applied to students. Effect size is a measure of the effect of a variable on other variables [8]. The formula used:

$$
\mathrm{d}=\frac{M_{A}-M_{B}}{\sqrt{\frac{S d_{A}^{2}-S d_{B}^{2}}{2}}}
$$


Note :

$\mathrm{d}=$ Effect Size

MA $=$ The average $\mathrm{N}$-Gains score of the experimental class

$\mathrm{MB}=$ average $\mathrm{N}-$ Gains score of control class

$\mathrm{SdA}=$ Standard deviation of the experimental class

$\mathrm{SdB}=$ Standard deviation of the control class

The effect size is presented in Table 2.

TABLE 2. EFFECT SIZE CRITERIA

\begin{tabular}{|c|c|}
\hline d-Value & Category \\
\hline $0<d \leq 0,2$ & Small \\
\hline $0,2<d \leq 0,8$ & Medium \\
\hline$d>0,8$ & Large \\
\hline
\end{tabular}

\section{RESULT AND DISCUSSION}

In the experimental class chemistry learning is implemented using the Google Forms with Problem Based Learning (PBL) model, while in the chemistry learning control class using the Problem Based Learning (PBL) model without the Google Forms.The results of the analysis of the pretest, posttest and N-Gain mastery of concepts and critical thinking skills of the two classes are stated in the following Table 3:

\section{TABLE 3. DATA ON THE RESULTS OF PRETEST, POSTTEST AND N-GAIN EXPERIMENT CLASS AND CONTROL CLASS}

\begin{tabular}{|c|c|c|c|c|c|c|c|}
\hline \multirow{2}{*}{ Class } & \multicolumn{2}{|c|}{ Pretest } & \multicolumn{2}{c|}{ Postest } & \multicolumn{2}{c|}{ N-Gain (96) } & \multirow{2}{*}{ Category } \\
\cline { 2 - 7 } & Mean & 5d & Mean & Sd & Mean & Sd & \\
\hline Experiment & 38,45 & 9,277 & 80,77 & 11,285 & 69,65 & 16,07 & Medium \\
\hline Centrol & 39,07 & 7,909 & 73,47 & 10,265 & 55,59 & 17,39 & Medium \\
\hline
\end{tabular}

Table 3 shows that both the control class and the experimental class obtained N-Gain with the medium category, but the N-Gain value of the experimental class is higher than the control class.Based on the difference in the mean $\mathrm{N}$-Gain in the two classes then measured the effectiveness of the learning studied using the effect size. The effect size test results are presented in Table 4 below:

TABLE 4. LEARNING EFFECTIVENESS DATA BASED ON EFFECT SIZE

\begin{tabular}{|c|c|c|c|c|}
\hline Class & $\begin{array}{c}\text { Average Score } \\
\text { N-Gain }\end{array}$ & $\begin{array}{c}\text { Standard } \\
\text { Deviation }\end{array}$ & $\begin{array}{c}\text { Site } \\
\text { Effect } \\
\text { (d) }\end{array}$ & Categon? \\
\hline Experiment & 69,65 & 16,07 & 0,82 & High \\
\hline Control & 55,89 & 17,39 & & \\
\hline
\end{tabular}

Based on the data in table 4 , the effectiveness of the learning of acid-base solutions using the Google Forms with Problem Based Learning (PBL) model is included in the high category with an effect size value of 0.82. This shows learning using the Problem Based Learning (PBL) model assisted by Google Forms is effective in improving students' critical thinking skills. Overall the N-Gain mean of the experimental class and the control class belongs to the medium category. The improvement of students' mastery of concepts and critical thinking skills between the control class and the experimental class is described in Figure 1 below:

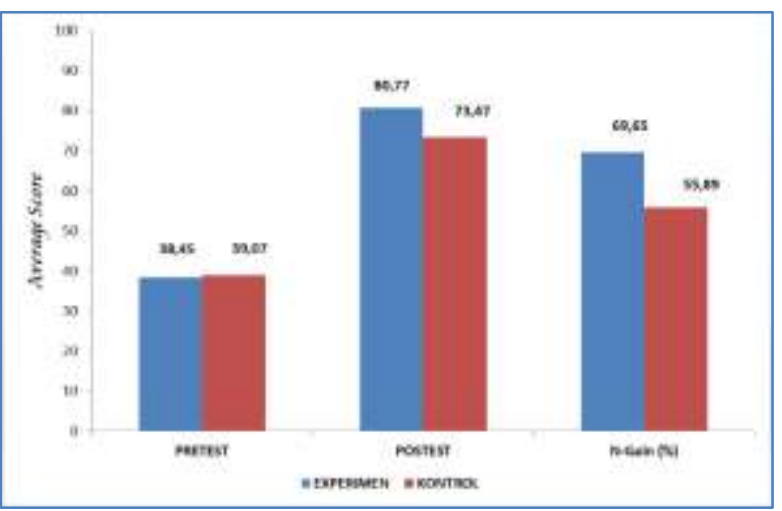

Fig. 1. The results of the analysis of the Pre-Test score, post-test and $\mathrm{N}-$ Gain mastery of concepts and students' Critical Thinking Ability

Based on the results of the study of mastery of concepts and improvement of critical thinking skills of students who get learning chemistry of acidic-basic solutions with Problem Based Learning (PBL) assisted by Google Forms is higher than students who get learning with Problem Based Learning (PBL) without assisted by Google Forms. All material has been added to Google Forms with the concept of Flipped Learning, when face to face in class, the teacher can focus more on a problem based approach. it is also used for remedial and enrichment teaching programs.

Learning activities in the experimental class, preparing students to act as problem solvers who can work together with other students, exposes students to situations that encourage them to be able to find problems and examine problems while submitting guesses and plans for resolution. Students better understand the concepts being taught, because they themselves discovered the concepts. Actively involves solving problems and demanding higher student thinking skills.

Students can feel the benefits of learning, because problems that are solved are directly linked to real life, this can increase students' motivation and interest in the material being studied. Make students more independent and mature, able to give aspirations and accept the opinions of others, instill positive social attitudes among students. Conditioning students in group learning that in addition to interacting with learning and their peers, so that the achievement of students' mastery learning can be expected. 
The results of this study are also supported by research results by: The development of chemical learning tools based on Problem Based Learning (PBL) can improve the competency of attitudes, knowledge and skills and increase student activities during the learning process [10], a good discussion is supported by the collaboration between members which shows good interaction within the group. Good cooperation is able to develop students 'way of thinking through problem solving and submit opinions and rebuttal so as to accommodate students' critical thinking [3].

\section{CONCLUSION}

Learning with Problem Based Learning (PBL) assisted by Google Forms can effectively improve students' mastery of concepts and critical thinking skills on acid-base solution. Based on the results of research and discussion, it can be concluded that the learning of acid and base solutions with Problem Based Learning (PBL) aided by Google Forms is effective in increasing students' critical thinking skills with an effect size of 0.82 (high category).

\section{REFERENCES}

[1] A. Alsa. "Pendekatan Kuantitatif Kualitatif dalam Penelitian Psikologi”. Pustaka Pelajar: Yogyakarta, 2004.

[2] L. A . Becker. "Effect Size Measures for Two Independent Groups", Journal: Effect Size Becker. 63, 2000, pp.928-937.

[3] Fascione, "Critical Thinking: What It is and Why it Counts", Insight Assessment, 2011.

[4] Fraenkel, J.R, Wallen, N.E, \& Hyun, H.H, "How to Design and evaluate Research in Education $8^{\text {th }}$ edition", McGrowHill: New York,2012.

[5] S. Hadi. "Metodologi Research Jilid 4", Yayasan Penerbit Fakultas Psikologi UGM Yogyakarta, 1985.

[6] H. Richard. R, "Design-Based Research a Primer for Physic Education Researchers", American Educational Research Association, 2004.

[7] Rusman, "Model-model Pembelajaran : Mengembangkan Profesionalisme Guru",(Edisi Kedua). Rajawali Pers : Jakarta. 2012.

[8] A. Santoso. "Studi Deskriptif Effect Size PenelitianPenelitian Di Fakultas Psikologi Universitas Sanata Dharma", Jurnal Penelitian Vol. 14 No. 1, 2010.

[9] Sukardi, "Metodologi Penelitian Pendidikan Kompetensi dan Praktiknya", PT Bumi Aksara: Jakarta, 2011.

[10] Syarnubi, "Pengembangan Perangkat Pembelajaran Kimia Berbasis Model Problem Based Learning Pada Siswa SMK Farmasi Tenggarong", Samarinda : Program Pascasarjana UNMUL, 2018. 